K

линико-морфологические особенности эластолитических гранулем

\author{
А.В. Патрушев, В.Р. Хайрутдинов, И.Э. Белоусова, А.В. Самцов
}

ФГБВОУ ВПО «Военно-медицинская академия им. С.М. Кирова» МО РФ 194044, Санкт-Петербург, ул. Академика Лебедева, д. 2

Представлены современные данные, касающиеся классификации, этиологии и патогенеза, клинической картины, патоморфологических особенностей и вариантов лечения эластолитических гранулем (ЭГ). Рассмотрены основные причины развития эластолиза и эластосрагоцитоза. Впервые в отечественной дерматовенерологии описаны три случая заболевания из группы ЭГ: актиническая гранулема и кольцевидная эластолитическая гигантоклеточная гранулема.

Ключевые слова: эластолитические гранулемы, эластофагоцитоз, актиническая гранулема, кольцевидная эластолитическая гигантоклеточная гранулема.

Контактная информация: alexpat2@yandex.ru. Вестник дерматологии и венерологии 2014; (4): 58—67.

\title{
Clinical and morphological features of elastolytic granulomas
}

\author{
A.V. Patrushev, V.R. Khairutdinov, I.E. Belousova, A.V. Samtsov
}

Military Medical Academy named after S.M. Kirov Ministry of Defense of the Russian Federation Akademika Lebedeva str., 2, St. Petersburg, 194044, Russia

The authors discuss current data on the classification, etiology and pathogenesis, clinical picture, pathologic features and treatment options of elastolytic granulomas (EGs). The authors disclose main aspects of elastolysis and elastophagocytosis development. Three cases of diseases from the EG group - actinic granuloma and annular elastolytic giant cell granuloma are described for the first time in the Russian literature.

Key words: elastolytic granulomas, elastophagocytosis, actinic granuloma, annular elastolytic giant cell granuloma.

Corresponding author: alexpat2@yandex.ru. Vestnik Dermatologii i Venerologii 2014; 4: 58—67. 
В настоящее время группа эластолитических гранулем включает в себя четыре заболевания, нозологическая самостоятельность которых на сегодняшний день окончательно не определена [1]:

- актиническая гранулема;

- кольцевидная эластолитическая гигантоклеточная гранулема;

ш атипичная форма липоидного некробиоза лица и волосистой части головы;

гранулема мультиформная.

Общими признаками для всей группы являются: преимущественное поражение открытых для воздействия солнечного излучения участков кожи (область головы, шеи, дистальных отделов конечностей), кольцевидная фрорма высыпаний (валик из папул по краю очагов, атрофия в центре) и характерные патогистологические признаки (гранулематозный инфильтрат, отсутствие муцина и очагов некробиоза, эластолиз, эластофрагоцитоз) [1].

Процесс эластофрагоцитоза, при котором происходит поглощение эластических волокон гистиоцитами и гигантскими многоядерными клетками, является ключевым в патогенезе данной группы дерматозов. Проведенные исследования показали, что при некоторых заболеваниях не только разрушенные, но и нормальные эластические волокна могут фагоцитироваться макрофрагами [2-4]. Количество эластических волокон в коже невелико. Так, в закрытой от воздействия инсоляции коже взрослого человека содержание эластина составляет $1-2 \%$ от общей сухой массы дермы. Обновление эластических волокон в коже происходит крайне медленно. При помощи трансмиссионной электронной микроскопии показано, что зрелые эластические волокна состоят из белка соединительной ткани эластина (центральный аморфный стержень), окруженного оболочкой из микрофибрилл [5].

Ген эластина человека локализуется на длинном плече хромосомы 7 человека в позиции 7q11.23. Он содержит 34 экзона и по протяженности занимает 45 килобаз $(\mathrm{kb})$ геномной ДНК. Матричная РНК эластина размером 3,5 kb содержит кодирующий сегмент из 2,2 kb и относительно большую 1,3 kb 3'-нетранслируемую область [6]. Базовая молекулярная структура эластина представляет собой линейный полипептид тропоэластин, который содержит около 800 аминокислот и имеет молекулярную массу 70 кД. Микрофибриллы состоят из структур трубчатой формы диаметром 10-12 нм. В их состав входят различные группы белков, состав и свойства которых на данный момент недостаточно изучены (фибриллины, фибулины, эмилины и др.) [5].

Причины повреждения эластических волокон могут быть различными. Имеют значение наследственные факторы, приводящие к синтезу дефектного эластина, активированию провоспалительного каскада и раз- витию эластолиза [7]. Другими причинами могут быть аутоиммунные и поствоспалительные процессы, при которых эластические волокна разрушаются различными ферментами [8-10]. Эластолитические энзимы (эластазы) включают аспарагиновые, цистеиновые, металло- и сериновые протеиназы, содержащиеся в различных микроорганизмах, змеином яде, макрофагах, полиморфно-ядерных лейкоцитах и опухолевых клетках. Эластазы, найденные в гранулоцитах, являются сериновыми протеиназами и содержатся в азурофильных гранулах [11]. Эластазы макрофрагов являются матричными металлопротеиназами (ММП) с более низким сродством к эластину [10].

Отмечено повышенное содержание макрофагальной ММР-12 в коже у пожилых пациентов [12, 13]. Другие типы MMP, особенно MMP-9, также могут вовлекаться в процесс эластолиза [14]. Деградация эластина не обязательно сопровождается процессом фагоцитоза. Например, фотостарение и возрастное старение кожи, при которых появляются дегенеративные изменения эластина (солнечный эластоз), не сопровождаются эластофрагоцитозом [15]. Известно, что некоторые структурные компоненты эластина (полипептиды) обладают биологической активностью. Показано, что гексапептид Val-Gly-ValAla-Pro-Gly обладает хемотаксическим воздействием на фрибробласты и моноциты [16], в то время как каппа-эластин может привлекать полиморфно-ядерные лейкоциты [17].

Несмотря на многочисленные исследования, посвященные изменениям эластической ткани под воздействием солнечного облучения [18-20], его роль в запуске эластофрагоцитоза до сих пор не ясна. Развитие эластофагоцитоза и потеря эластических волокон на открытых солнцу участках тела могут возникать при различных дерматозах $[21,22]$. І. Patroi и соавт. (2003) предположили, что ультрафиолетовое облучение индуцирует высвобождение MМР-9 из фибробластов и может привести к стойкой дегенерации волокон при среднедермальном эластолизе [23]. Согласно другим данным, эластофагоцитоз не всегда направлен только против поврежденных солнцем эластических волокон [24-27].

Поглощенные эластические волокна можно увидеть при микроскопическом исследовании в цитоплазме гистиоцитов и многоядерных гигантских клеток. Это явление может быть первичным процессом, когда сами эластические волокна являются мишенью фагоцитов, или вторичным, связанным с основным заболеванием. Перечень заболеваний, при которых может встречаться эластофрагоцитоз, представлен в таблице [28-30].

B 1975 г. J. O'Brien описал наблюдение пациента с очагами поражения кожи кольцевидной формы, которые возникали на открытых для солнечного облучения участках тела. Патоморфологические изменения 


\begin{tabular}{|c|c|c|}
\hline $\begin{array}{c}\text { Заболевания, } \\
\text { при которых эластофагоцитоз } \\
\text { является характерным признаком }\end{array}$ & $\begin{array}{c}\text { Заболевания, } \\
\text { при которых эластофагоцитоз } \\
\text { встречается часто }\end{array}$ & $\begin{array}{c}\text { Заболевания, } \\
\text { при которых эластофагоцитоз } \\
\text { встречается редко }\end{array}$ \\
\hline \multirow{2}{*}{$\begin{array}{l}\text { Эластолитические заболевания: } \\
\text { - эластолитические гранулемы; } \\
\text { — эластолиз среднего участка дермы } \\
\text { (mid-dermal elastolysis); } \\
\text { — cocoчково-дермальный эластолиз } \\
\text { (papillary-dermal elastolysis) }\end{array}$} & \multirow[t]{2}{*}{$\begin{array}{l}\text { Воспалительные дерматозы: } \\
\text { - кольцевидная гранулема; } \\
\text { - склеротический лишай; } \\
\text { - саркоидоз }\end{array}$} & $\begin{array}{l}\text { Эластолитические заболевания: } \\
\text { — анетодермия; } \\
\text { — приобретенная вялая кожа (acquired cutis laxa); } \\
\text { — псевдоксантома эластическая }\end{array}$ \\
\hline & & $\begin{array}{l}\text { Воспалительные дерматозы: } \\
\text { - некробиотическая ксантогранулема; } \\
\text { — бляшечная склеродермия }\end{array}$ \\
\hline \multirow[t]{2}{*}{$\begin{array}{l}\text { Злокачественные опухоли: } \\
\text { - синдром гранулематозной вялой кожи } \\
\text { (вариант грибовидного микоза) }\end{array}$} & \multirow[t]{2}{*}{$\begin{array}{l}\text { Злокачественные опухоли: } \\
\text { — гранулематозный грибовидный микоз; } \\
\text { — атипичная псевдоксантома }\end{array}$} & $\begin{array}{l}\text { Злокачественные и доброкачественные опухоли: } \\
\text { - дерматофиброма; } \\
\text { - кератоакантома; } \\
\text { - базально-клеточная карцинома }\end{array}$ \\
\hline & & $\begin{array}{l}\text { Инфекции кожи: } \\
\text { - лейшманиоз; } \\
\text { - бластомикоз; } \\
\text { - лепра }\end{array}$ \\
\hline
\end{tabular}

характеризовались исчезновением эластических волокон по периферии очагов поражения в результате воспалительной реакции с участием гистиоцитов и гигантских клеток. Он назвал это заболевание актиническая гранулема (АГ) [31]. Его концепция развития гранулематозной реакции на солнечной эластоз получила противоречивые оценки специалистов. Некоторые авторы считали, что это состояние представляет собой вариант кольцевидной гранулемы, локализующейся на открытых солнцу частях тела [31, 32].

Заболевание начинается с появления одной или нескольких сгруппированных розовых папул, которые образуют кольцевидные поражения на открытых солнцу участках шеи, лица, груди и рук. Кольцевидный валик слегка приподнят и имеет ровные границы. Элементы медленно растут по периферии, сливаются или становятся прерывистыми, в центре очага кожа возвращается в норму или слегка атрофирована. Диаметр отдельных очагов может достигать 6 см, в редких случаях происходит спонтанная ремиссия. Предрасполагающим фактором развития заболевания является светлая кожа с наличием веснушек. Заболевание встречается у пациентов обоих полов в равной степени, чаще в возрасте 40 лет и старше [33]. В некоторых случаях развитие АГ было ассоциировано с алопецией, рецидивирующим полихондритом, контагиозным моллюском и кожным амилоидозом. Сообщалось о манифестации заболевания после фототоксической реакции на доксициклин [1, 34].

При гистологическом исследовании можно условно выделить три зоны, в которых изменения принципиально различны. В коже, окружающей кольцевидный валик по периферии, наблюдается солнечный (актинический) эластоз - явление, сопровождающе- еся аккумуляцией эластической ткани в дерме под воздействием солнечного облучения. Эластические волокна в верхней части дермы утолщаются и закручиваются, формируя «клубки», которые становятся базофильными при окраске гематоксилином и эозином.

В основании папул, формирующих валик, патоморфологические изменения характеризуются наличием в дерме инфильтрата из гистиоцитов и гигантских клеток инородных тел, которые поглощают эластические волокна. В инфильтрате также могут обнаруживаться лимфоциты, плазматические клетки и эозинофилы. В центральной зоне наблюдается полная или почти полная потеря эластических волокон. Количество коллагена в этой зоне не изменено или слегка увеличено, иногда наблюдается незначительный склероз. В отличие от липоидного некробиоза и кольцевидной гранулемы, некробиотические изменения и отложения муцина обычно отсутствуют. В некоторых случаях гистиоцитов может быть значительно больше, чем многоядерных гигантских клеток, иногда инфильтраты могут напоминать туберкулоидную гранулему [1, 32].

Предполагается, что существует клеточно-опосредованный иммунный ответ на антигенные детерминанты, образующиеся в эластических волокнах при их повреждении солнечной радиацией [30]. Данное обстоятельство является отличительной особенностью АГ от других заболеваний, протекающих с явлениями эластоклазии, при которых эластофрагоцитоз представляет собой вторичную реакцию на эластические волокна, измененные опухолевым, воспалительным или другим, еще неизвестным первичным процессом $[1,35]$. 
Весомые доказательства в вопросе самостоятельности нозологической формы АГ были представлены І. Al-Hoqail и соавт. (2001). Авторы провели сравнение гистологических изменений в биоптатах кожи 14 случаев АГ и 16 случаев кольцевидной гранулемы (КГ), из которых 8 находились на открытых, а 8 на закрытых для солнечного облучения участках тела. Они обнаружили наличие муцина и отсутствие гигантских клеток при КГ в отличие от АГ, для которой было характерно наличие гигантских клеток с большим количеством ядер (более 12). Данные различия имели высокий показатель статистической значимости. Тип и расположение гранулем в дерме также различалось: при АГ гранулемы были ближе к саркоидному типу с многочисленными гигантскими клетками инородного тела, в то время как при КГ наблюдались гранулемы некробиотического типа с частоколом из гистиоцитов вокруг и редко встречающимися гигантскими клетками. Воспалительный инфильтрат располагался в поверхностных слоях дермы при АГ, а при КГ изменения наблюдались во всех слоях дермы [36].

Иммуногистохимические исследования показали наличие лизоцима в гигантских клетках и преобладание CD4+ Т-клеток в лимфоцитарном инфильтрате при АГ. Ультраструктурное исследование выявило как внеклеточную, так и внутриклеточную ферментацию эластических волокон [1].

В 1979 г. С. Hanke и соавт., впервые используя термин «кольцевидная эластолитическая гигантоклеточная гранулема» (КЭГКГ), описали кольцевидные поражения кожи, связанные с гранулематозным воспалением и потерей эластических волокон [37]. В дальнейшем этот термин был использован некоторыми авторами для описания всех случаев, характеризующихся кольцевидными бляшками с гистологическими признаками эластофрагоцитоза и наличием гранулем, содержащих многоядерные гигантские клетки [1, 37]. КЭГКГ обычно развивается как на открытых, так и на закрытых от солнца частях тела [38, 39]. Клиническая картина КЭГКГ представлена кольцевидными бляшками с эритематозным приподнятым краем и атрофическим гипопигментированным центром, а также, в редких случаях, изолированными полушаровидными милиарными и лентикулярными папулами [38, 40]. Рост медленный, центробежный. Поражения обычно более распространенные, чем при АГ [37]. Характерными особенностями данного заболевания являются хроническое течение и недостаточный терапевтический ответ на различные методы лечения [41].

Патогенез КЭГКГ до конца не изучен. Помимо влияния ультрафиолетового излучения [42] выявлены ассоциации между развитием КЭГКГ и сахарным диабетом (СД), саркоидозом, лимфропролиферативными заболеваниями, раком предстательной железы [37, $43,44]$. Не исключается роль нейротрофических нарушений в развитии дерматоза [45].
Недавнее исследование японских авторов продемонстрировало возможную роль СД в структурном повреждении эластических волокон. Показано, что 37\% пациентов с КЭГКГ имели манифестный или скрытый СД [46]. Такие данные создают патогенетическое обоснование возможности сосуществования одновременно двух заболеваний - КЭГКГ и КГ, так как хорошо известно о некробиотических изменениях коллагена в коже при СД. Такая гибридная модель была описана по меньшей мере в 6 случаях [47], что указывает на общие этиологические и патогенетические механизмы с возможным влиянием системных заболеваний, таких как СД [48].

Гранулематозное воспаление и эластофрагоцитоз могут приводить к сокращению и последующей полной потере эластических волокон с развитием вторичной анетодермии [49]. Это патологическое состояние, как правило, ограничено кожей. В то же время в литературе описан случай с поражением глаз, лимфатических узлов и кишечника [50].

Методы лечения КЭГКГ обладают различной степенью эффективности и включают назначение клофазимина, хлорохина, гидроксихлорохина, системные и местные глюкокортикостероиды, ПУВА-терапию [52, 53].

Атипичная форма липоидного некробиоза лица и волосистой части головы (АЛН) была первым заболеванием из группы эластолитических гранулем, которую описали в 1967 г. G. Dowling и E. Wilson-Jones [54]. Заболевание характеризуется кольцевидными элементами, локализующимися на коже верхней части лица и волосистой части головы. Болеют преимущественно женщины. Средний возраст больных во время дебюта болезни составляет около 35 лет. Высыпания могут разрешиться самостоятельно или сохраняться В течение многих лет. В отличие от липоидного некробиоза они заживают без формирования рубцов или алопеции, не имеют желтоватого оттенка, на поверхности элементов отсутствуют телеангиэктазии. У некоторых пациентов отмечаются типичные высыпания липоидного некробиоза на других участках [1]. В центральной зоне очагов поражения происходит потеря эластической ткани, в периферическом приподнятом крае имеется лимфоцитарный и гистиоцитарный дермальный инфильтрат, располагающийся между коллагеновыми пучками. Инфильтрат включает многоядерные гигантские клетки, некоторые из них содержат астероидные тела. Некробиотические изменения и отложения муцина в дерме описаны не были [1, 54].

Гранулема мультиформная (ГМ, гранулематозный дерматит) была первоначально выделена как самостоятельная нозологическая фрорма. Это связано с потенциальной значимостью данного заболевания в диффференциальной диагностике с туберкулоидной лепрой, которую она напоминает клинически и в некоторой степени патоморфологически [1]. ГМ является 
реактивным заболеванием кожи неизвестной этиологии, клинически характеризующимся сливающимися кольцевыми элементами, а гистологически - фокусами некробиоза и гистиоцитарными гранулемами [55]. Заболевание встречается в странах Центральной Африки (впервые описано в Нигерии), в Индонезии и в Индии. Болеют одинаково часто представители обоих полов, большинство пациентов имеют возраст 40 лет или старше. Высказано предположение, что мульти-

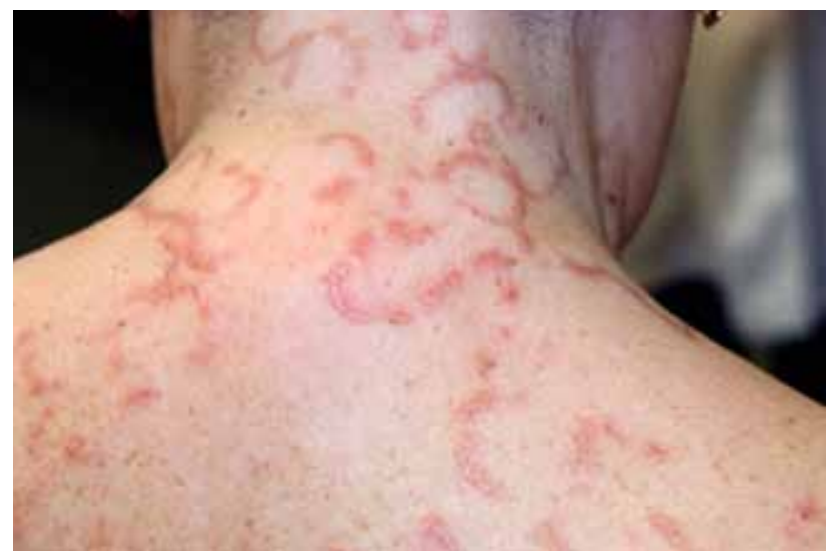

КЭГКГ. Очаги поражения на коже задРис. 1. ней поверхности шеи и верхней части спины в виде колец и полуколец диаметром от 3 до 5 см

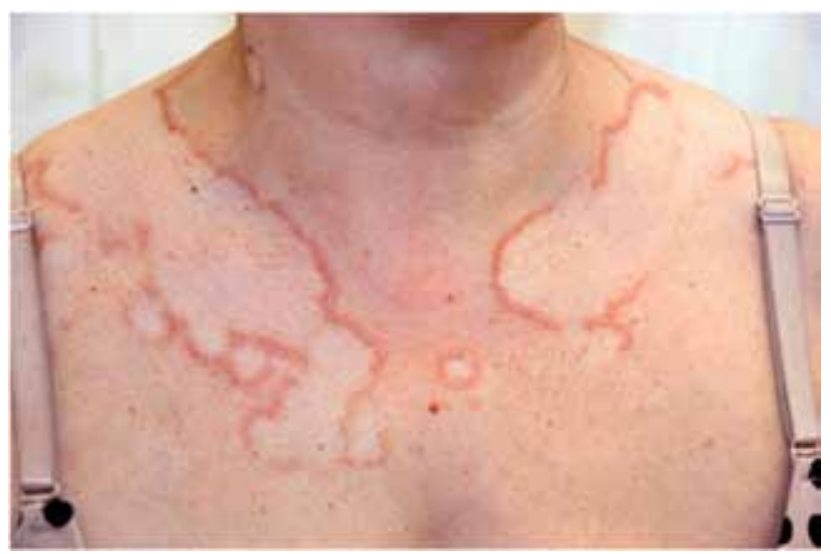

КЭГКГ. Гигантские очаги поражения неправильной формы на коже груди,

Рис. 2. шеи, представленные валиком из розово-красных полушаровидных папул по периферии и гипопигментацией в центральной части формная гранулема является вариантом кольцевидной гранулемы или липоидного некробиоза. Другие авторы считают, что заболевание связано с АГ [1]. Патоморфологические признаки ГМ характеризуются гранулематозным воспалением с наличием гистиоцитов, многоядерных гигантских клеток, лимфоцитов, эозинофилов и плазматических клеток, а также эластоклазией. В центральной части очагов происходит разрушение эластических волокон с незначительным фриброзом. Отложений жира и муцина в очагах поражения обнаружено не было [1].

В клинике кожных и венерических болезней Военно-медицинской академии (ВМА) мы наблюдали трех пациенток, которым были установлены диагнозы КЭГКГ и АГ.

Пациентка Б., 58 лет, считает себя больной с 2007 г., когда впервые отметила появление высыпаний на коже тыла кистей. С течением времени высыпания распространились на область шеи, груди, спины, живота, верхних и нижних конечностей. Неоднократно проходила амбулаторное и стационарное лечение в дерматологических стационарах с диагнозом «диссеминированная кольцевидная гранулема», получала системную терапию сосудистыми препаратами, витаминами, а также наружное лечение сильными и сверхсильными топическими глюкокортикостероидами. Высыпания частично разрешались, но не исчезали полностью. В январе 2014 г. в связи с очередным обострением дерматоза госпитализирована в клинику кожных болезней ВМА. Дерматологический статус: на коже шеи (рис. 1), груди (рис. 2), спины, живота, преимущественно разгибательных поверхностей верхних и нижних конечностей имеются высыпания в виде полушаровидных милиарных и лентикулярных папул бледно-красного цвета, которые сгруппированы в кольцевидные бляшки диаметром от 3 до 25 см, а также образуют фигуры неправильной формы в виде полуколец и гирлянд. Папулы располагаются по периферии очагов, в центре отмечаются явления атрофрии кожи, наиболее заметные в области тыльной поверхности кистей.

Проведена диагностическая биопсия кожи. При гистологическом исследовании отмечается атрофия эпидермиса, в верхней части дермы располагаются плотные гранулематозные инфильтраты, состоящие из многочисленных гигантских клеток и гистиоцитов, с примесью небольшого количества лимфоцитов и эозинофильных лейкоцитов (рис. 3). Гистиоциты встречаются хаотично, «палисадообразный» порядок, характерный для КГ, отсутствует. В зоне инфильтрата визуализируются слегка утолщенные и базофильно окрашенные эластические волокна, которые фрагоцитируются гигантскими клетками (рис. 4). Муцин и зоны некробиоза коллагена отсутствуют. При окраске орсеином обнаруживается частичная потеря эластических волокон в верхней части дермы. 

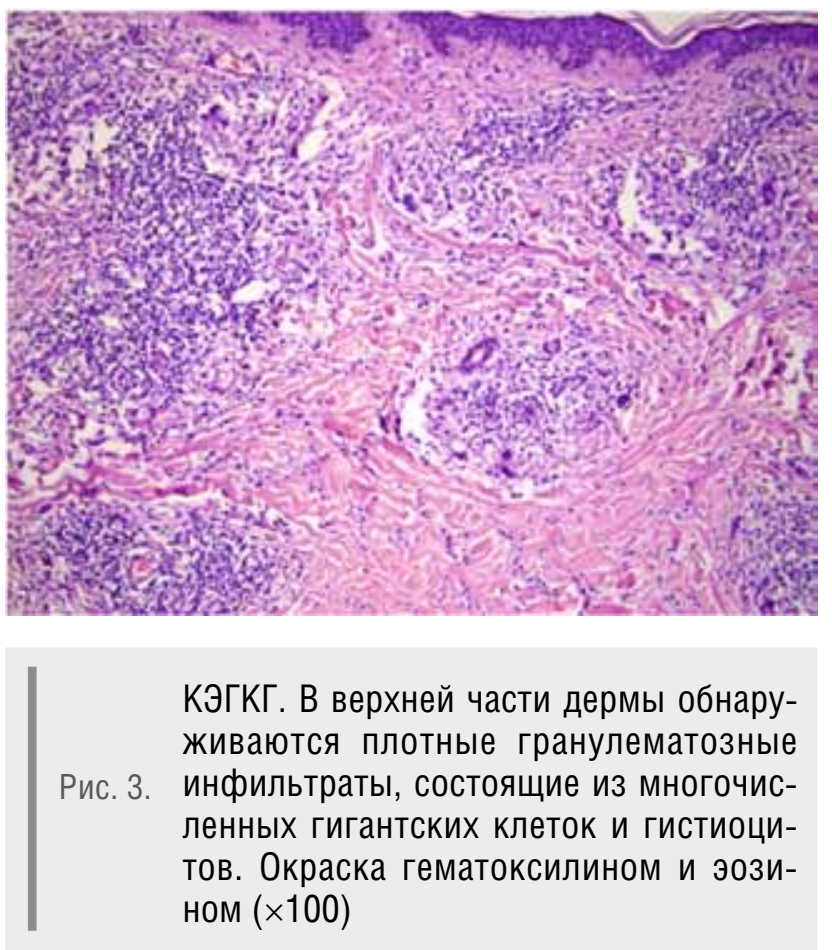

На основании данных клинической картины и гистологического исследования был установлен диагноз кольцевидная эластолитическая гигантоклеточная гранулема. Проведено лечение: гидроксихлорохин перорально 200 мг 2 раза в сутки, 3 курса по 10 дней с перерывами 5 дней; обкалывание отдельных очагов раствором «Дипроспан» 1,0 мл однократно, мазь 0,05\% клобетазола пропионата под окклюзионную повязку на область высыпаний 1 раз в сутки в течение 14 дней. Через 2 мес. при контрольном осмотре отмечался положительный эффект терапии в виде полного разрешения очагов поражения на коже шеи, груди, спины, живота и частичного - на конечностях.

Пациентка Д., 26 лет, обратилась в клинику 12 февраля 2014 г. с жалобами на прогрессирующие кожные высыпания. В течение 3 лет от момента начала заболевания неоднократно обращалась за медицинской помощью, но диагноз установлен не был. При обследовании общие анализы крови и мочи, анализ кала на яйца гельминтов, биохимические и острофазовые показатели, данные ультразвукового исследования органов брюшной полости, компьютерной томографии органов грудной полости - без патологии. Со стороны других органов и систем диагностирован синдром поликистозных яичников. Дерматологический статус: на фоне неизмененной кожи в области разгибательных поверхностей предплечий, плеч, латеральной поверхности голеней и бедер имеются полушаровидные милиарные и лентикулярные папулы синюшно-красного

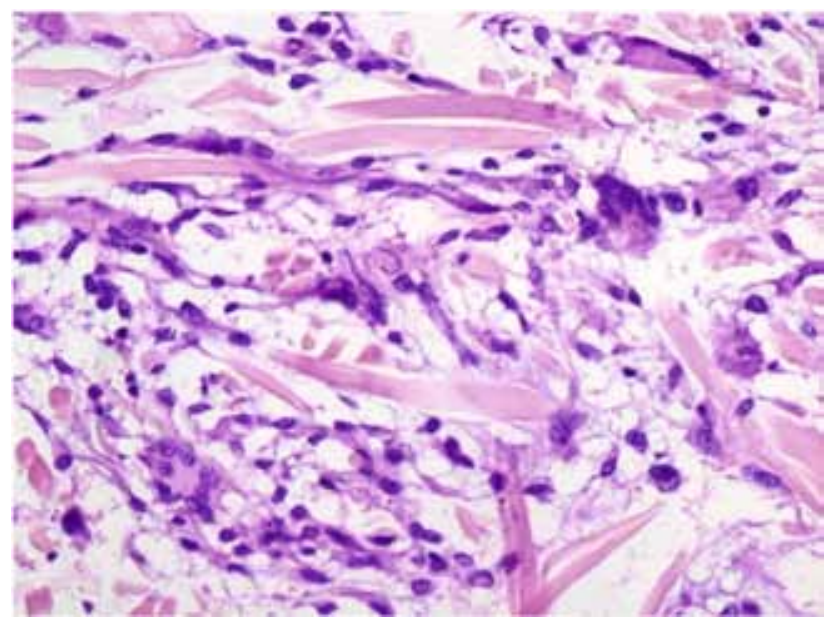

Эластофрагоцитоз при КЭГКГ. В зоне инфильтрата визуализируются слегка

Рис. 4. утолщенные и базофильно окрашенные эластические волокна, которые фагоцитируются гигантскими клетками. Окраска гематоксилином и эозином $(\times 400)$

цвета, местами с «пупкообразным» вдавлением в центре (рис. 5). Вторичные морфологические элементы кожной сыпи представлены очагами атрофии округлой фрормы, диаметром от 1 до 5 см, белесоватого цвета, с морщинистой поверхностью (рис. 6). Эластичность кожи в очагах поражения снижена, имеются грыжеобразные выпячивания или западения в виде ямки.

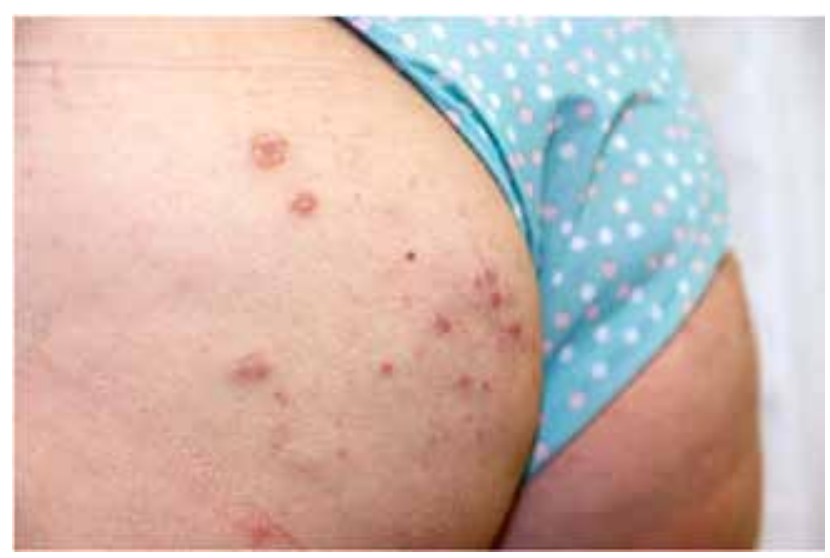

Рис. 5 Милиарные и лентикулярные полушаровидные папулы синюшно-красного цвета у больной КЭГКГ 

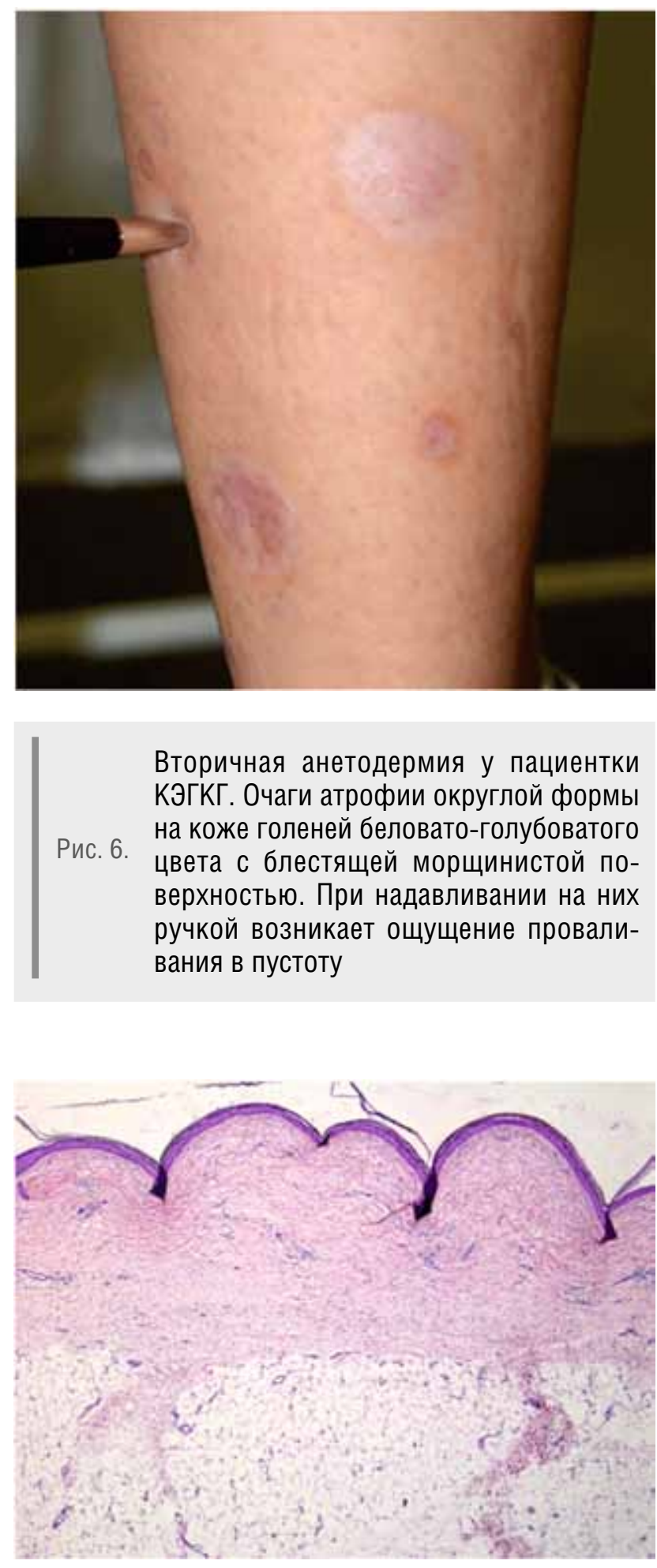

КЭГКГ. Практически полное отсутствие

Рис. 7. эластических волокон в верхних и средних отделах дермы. Окраска гематоксилином и эозином $(\times 100)$
Выполнены две диагностические биопсии кожи в области первичных и вторичных элементов. В первом биоптате на всем протяжении дермы в верхних слоях обнаруживаются очаговые инфрильтраты гранулематозного строения с примесью большого количества гигантских клеток. Встречаются явления эластофагоцитоза. Эластические волокна в зонах инфильтрата отсутствуют и сохранены только в участках дермы, свободной от инфильтрата. Во втором биоптате эпидермис атрофирован. Дерма резко истончена, встречаются редкие лимфоцитарные периваскулярные инфиильтраты. Эластические волокна практически полностью отсутствуют в верхних и средних отделах дермы, частично сохранены в нижних отделах (рис. 7).

На основании данных клинической картины и гистологического исследования установлен диагноз кольцевидная эластолитическая гигантоклеточная гранулема с развитием вторичной анетодермии.

Проведена терапия: гидроксихлорохин внутрь по 200 мг 2 раза в сутки курсами по 10 дней с 5-дневным перерывом (всего 4 курса). Через 3 мес. от начала лечения наблюдалась незначительная положительная динамика в виде уменьшения количества новых высыпаний. Для коррекции терапии рекомендовано подключить обкалывание папулезных эфффлоресценций раствором «Дипроспан» по 1,0 мл 1 раз В 2 нед. На фооне данного лечения через 2 мес. отмечен положительный эфрфект - отсутствие новых элементов и частичное разрешение имеющихся высыпаний.

Пациентка К., 47 лет, проходила амбулаторное обследование в клинике в сентябре 2013 г. При поступлении предъявляла жалобы на распространенные высыпания на коже, появившиеся около 3-4 мес. назад после продолжительной инсоляции. В ходе обследования данных о наличии сопутствующих заболеваний получено не было. Дерматологический статус: на коже переднебоковых поверхностей шеи, груди в зоне декольте (рис. 8) и верхней части спины (рис. 9) имеется большое количество милиарных и лентикулярных полушаровидных папул бледно-красного цвета, размером от 0,3 до 1,0 cм, местами образующих фигуры в виде колец и полуколец. Выполнено гистологическое исследование кожи: эпидермис атрофирован, в дерме на фооне картины актинического эластоза обнаруживается гранулематозный инфильтрат с явлениями эластофрагоцитоза. Инфильтрат состоит из гистиоцитов и гигантских клеток инородных тел, в цитоплазме которых визуализируются обрывки эластических волокон. Проведено лечение: внутрикожные микроинъекции раствора «Дипроспан» 1,0 мл 1 раз в 2 нед., N 6. Через 3 мес. высыпания полностью разрешились, на месте некоторых первичных элементов сыпи сохранились поверхностные очаги атрофии. 


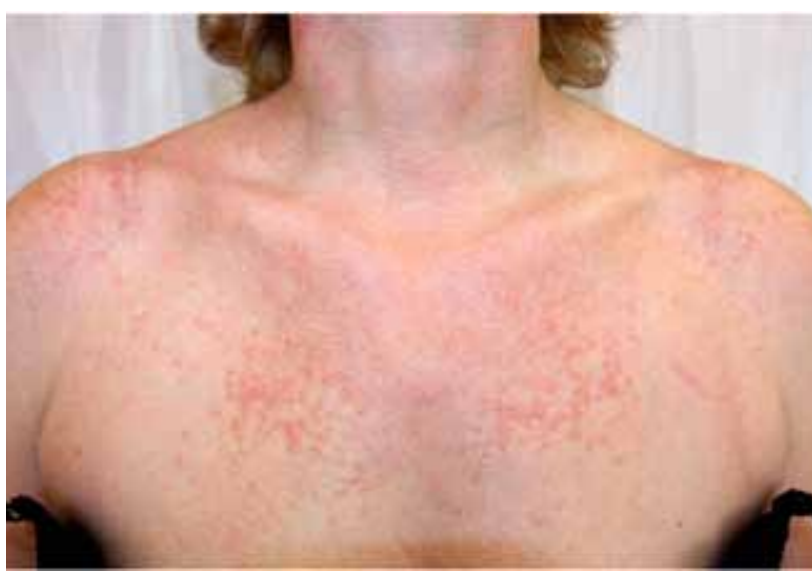

Рис. 8.

Розово-желтые милиарные и лентикулярные полушаровидные папулы на коже груди больной АГ

\section{Обсуждение}

Вопрос о нозологической самостоятельности заболеваний, входящих в группу эластолитических гранулем, на сегодняшний день остается открытым. Первым заболеванием из этой группы в 1967 г. был описан атипичный липоидный некробиоз лица и волосистой части головы. Затем J. O'Brien в 1975 г. выдвинул концепцию развития гранулематозного воспаления на актинический эластоз и предложил использовать для аналогичных высыпаний термин «актиническая гранулема» [31].

C. Hanke и соавт. в 1979 г. на основании наблюдения 5 пациентов с кольцевидными очагами поражения, эластофрагоцитозом и потерей эластических волокон пришли к выводу об отсутствии как клинических, так и патоморфологических различий между этими больными и пациентами с АЛН и АГ. Они подвергли серьезной критике термин «атипичный липоидный некробиоз» на основании того, что ни признаков некробиоза, ни отложения липидов в очагах поражения не отмечалось. Термин «актиническая гранулема» также вызывал вопросы, так как ассоциация солнечного эластоза и гранулематозного воспаления, по мнению авторов, не обязательно подразумевает причинно-следственную связь. Выдвинуто предложение использовать единый термин «кольцевидная эластолитическая гигантоклеточная гранулема», который бы объединил АЛН и АГ [37].

Мы разделяем точку зрения авторов, считающих КЭГКГ отдельной нозологической формой в группе эластолитических гранулем, которая отличается отсутствием тяжелого солнечного эластоза, характерного для АГ. По нашему мнению, действительно, между АЛН и КЭГКГ нет существенных различий, в то вре-

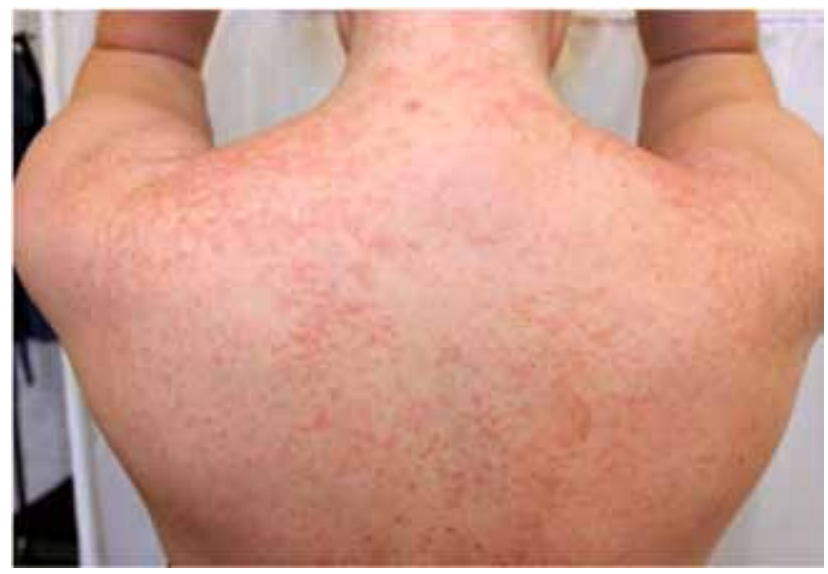

Рис. 9.
и слив Большое количество изолированных
полушаровидных пентикулярных розовых

мя как последний термин более предпочтителен, потому что отражает клинические и морфологические особенности заболевания. Что касается АГ, то здесь можно выделить такие отличительные признаки, как связь появления высыпаний с инсоляцией, а также выраженный солнечный эластоз в верхней части дермы.

Диагностику АГ или КЭГКГ следует проводить с обязательным выполнением патоморфологического исследования, а врач-патоморфолог должен обладать достаточно высокой квалификацией для определения признаков эластофрагоцитоза.

Уделяя внимание клиническим особенностям, можно констатировать, что в большинстве случаев для клинической картины эластолитических гранулем характерны кольцевидные, центробежно растущие очаги поражения. Однако могут встречаться и изолированные папулезные высыпания, как в представленных нами наблюдениях пациенток с АГ и КЭГКГ, при которых только гистологическое исследование позволило установить правильный диагноз.

Исходом эластолитических гранулем может явиться развитие вторичной анетодермии в результате полной потери эластических волокон в верхней части дермы. Известно, что первичная анетодермия может начинаться с так называемой воспалительной стадии, проявляющейся развитием эритематозных пятен и папул (тип Ядассона - Пелиццари). Гистологическая картина таких элементов характеризуется лимфоцитарным периваскулярным и интерстициальным инфильтратом и будет отличаться от эластолитических гранулем отсутствием эластофагоцитоза и гранулематозного инфрильтрата из гистиоцитов и гигантских многоядерных клеток. Этот фракт подтверждается как данными литературы [56], так и нашими наблюдениями. 


\section{Заключение}

Клиническая картина эластолитических гранулем не является специфичной и имеет значительное сходство с кольцевидной гранулемой и липоидным некробиозом. В связи с этим пациентам с предварительным диагнозом данных дерматозов и локализацией высыпаний на открытых солнцу участках тела или распространенным характером поражения необходимо проведение гистологического исследования для под- тверждения диагноза и исключения эластолитических гранулем.

Для лечения актинической гранулемы и кольцевидной эластолитической гигантоклеточной гранулемы целесообразно применять производные 4-аминохинолина (хлорохин, гидроксихлорохин) и внутриочаговое микроинъекционное введение пролонгированных глюкокортикостероидов.
1. David Weedon. Weedon's Skin Pathology. 3rd edition. Churchill Livingstone; 2009.

2. Harmon C.B., Su W.P., Gagne E.J. et al. Ultrastructural evaluation of mid-dermal elastolysis. J Cutan Pathol 1994; 21: 233_-8.

3. Fimiani M., Mazzatenta C., Alessandrini C. et al. Mid-dermal elastolysis: an ultrastructural and biochemical study. Arch Dermatol Res 1995; 287: 152-7.

4. Hashimoto K., Tye M.J. Upper dermal elastolysis: a comparative study with mid-dermal elastolysis. J Cutan Pathol 1994; 21: 533-40.

5. Дерматология Фицпатрика в клинической практике: в 3 т. Пер. с англ. ; общ. ред. акад. А.А. Кубановой. М.: Издательство Панфиилова; БИНОМ. Лаборатория знаний; 2012.

6. Fasio M. J., Mattei M. G., Passage E. et al. Human elastin gene: new evidence for localization of elastin to the long arm of chromosome 7. Am J Hum Genet 1991; 48: 696-703.

7. Reed W.B., Horowitz R.E., Beighton P. Acquired cutis laxa: primary generalized elastolysis. Arch Dermatol 1971; 103: 661—9.

8. Gambichler T., Linhart C., Wolter M. Middermal elastolysis associated with Hashimoto's thyroiditis. J Eur Acad Dermatol Venereol 1999; 12: $245-9$.

9. Kirsner R.S., Falanga V. Features of an autoimmune process in mid-dermal elastolysis. J Am Acad Dermatol 1992; 27: 832-4.

10. Werb Z., Banda M.J., McKerrow J.H. et al. Elastases and elastin degradation. J Invest Dermatol 1982; 79: 154-9.

11. Loo W.J., Rytina E., Banfield C. Elastophagocytosis: a feature of resolving Sweet's syndrome. J Eur Acad Dermatol Venereol 2004; 18 : 471-3.

12. Taddese S., Weiss A.S., Neubert R.H. et al. Mapping of macrophage elastase cleavage sites in insoluble human skin elastin. Matrix Biol 2008; 27: 420—8.

13. Vaalamo M., Kariniemi A.L., Shapiro S.D. et al. Enhanced expression of human metalloelastase (MMP-12) in cutaneous granulomas and macrophage migration. J Invest Dermatol 1999; 112: $499-505$

\section{Литература}

14. Patroi I., Annessi G., Girolomoni G. Mid-dermal elastolysis: a clinical, histologic, and immunohistochemical study of 11 patients. J Am Acad Dermatol 2003; 48: 846-51.

15. Suwabe H., Serizawa A., Kajiwara H. et al. Degenerative processes of elastic fibers in sun-protected and sun-exposed skin: immunoelectron microscopic observation of elastin, fibrillin-1, amyloid P component, lysozyme and alpha1antitrypsin. Pathol Int 1999; 49: 391—402.

16. Senior R.M., Griffin G.L., Mecham R.P. et al. Val-Gly-Val-Ala-Pro-Gly, a repeating peptide in elastin, is chemotactic for fibroblasts and monocytes. J Cell Biol 1984; 99: 870—4.

17. Hauck M., Seres I., Kiss I. et al. Effects of synthesized elastin peptides on human leukocytes. Biochem Mol Biol Int 1995; 37: 45—55.

18. Bernstein E.F., Underhill C.B., Hahn P.J. et al. Chronic sun exposure alters both the content and distribution of dermal glycosaminoglycans. Br J Dermatol 1996; 135: 255—62.

19. Cavarra E., Fimiani M., Lungarella G. et al. UVA light stimulates the production of cathepsin $G$ and elastase-like enzymes by dermal fibroblasts: a possible contribution to the remodeling of elastotic areas in sun-damaged skin. Biol Chem 2002; 383: 199_-206.

20. Brennan M., Bhatti H., Nerusu K. C. et al. Matrix metalloproteinase- 1 is the major collagenolytic enzyme responsible for collagen damage in UV-irradiated human skin. Photochem Photobiol 2003; 78: 43-8.

21. Abbas 0., Chatrath V., Goldberg L. J. Elastophagocytosis in extragenital lichen sclerosus. J Cutan Pathol 2010; 37: 1032-7.

22. Ragaz A., Ackerman A. B. Is actinic granuloma a specific condition? Am J Dermatopathol 1979; 1: 43-50.

23. Patroi I., Annessi G., Girolomoni G. Mid-dermal elastolysis: a clinical, histologic, and immunohistochemical study of 11 patients. J Am Acad Dermatol 2003; 48: 846-51.

24. Gunes P., Goktay F., Mansur A.T. et al. Collagen-elastic tissue changes and vascular involvement in granuloma annulare: a review of 35 cases. J Cutan Pathol 2009; 36: 838 —44.
25. Barnhill R.L., Goldenhersh M.A. Elastophagocytosis: a non-specific reaction pattern associated with inflammatory processes in sun-protected skin. J Cutan Pathol 1989; 16 : 199-202.

26. Burket J.M., Zelickson A.S. Intracellular elastin in generalized granuloma annulare. J Am Acad Dermatol 1986; 14: 975-81.

27. Friedman-Birnbaum R., Weltfriend S., Kerner H. Elastic tissue changes in generalized granuIoma annulare. Am J Dermatopathol 1989; 11: 429-33.

28. Sweeney E.C., McDermott M. Tumor-related cutaneous elastophagocytosis. J Clin Pathol 1996; 49: 81—3.

29. Gunes P., Goktay F., Mansur A.T. et al. Collagen-elastic tissue changes and vascular involvement in granuloma annulare: a review of 35 cases. J Cutan Pathol 2009; 36: 838 — 44.

30. El-Khoury J., Kurban M., Abbas 0. Elastophagocytosis: Underlying mechanisms and associated cutaneous entities. J Am Acad Dermatol 2014; 18: 1-10.

31. O'Brien J.P. Actinic granuloma: an annular connective tissue disorder affecting sun-and heatdamaged (elastotic) skin. Arch Dermatol 1975; 111: 460-6.

32. O'Brien J.P. Is actinic granuloma a specific condition? Am J Dermatopathol 1979; 1 (1): $51-3$.

33. Steffen Ch. The Man Behind the Eponym. John P.0. Brien - Actinic Granuloma (O'Brien). Am J Dermatopathol 2002; 24 (3): 264-66.

34. Delgado-Jimenez Y., Perez-Gala S., Penas P. F. et al. O'Brien actinic granuloma presenting as alopecia. J Eur Acad Dermatol Venereol 2006; 20: 226 .

35. Wilson E.J. Actinic Granuloma. Am J Dermatopathol 1980; 2 (1): 89—90.

36. Al-Hoqail I. A., Al-Ghambi A., Martinka M. et al. Actinic granuloma and granuloma annulare: are they the same condition? Paper presented at the 38th annual meeting of the American Society of Dermatopathology. J Cutan Pathol 2001; 28: 556 . 
37. Hanke C.W., Bailin P.L., Roenigk H.H. Annular elastolytic giant cell granuloma (a clinicopathologic study of five cases and a review of similar entities). J Am Acad Dermatol 1979; 1: 413-21.

38. Pock L., Blazkova J., Caloudova H. et al. Annular elastolytic giant cell granuloma causes an irreversible disappearance of the elastic fibres. J Eur Acad Dermatol Venereol 2004; 18 (3): 365-68.

39. Yanagihara M., Kato F. Mori S. Extra- and intracellular digestion of elastic fibers by macrophages in annular elastolytic giant cell granuIoma. J Cutan Pathol 1987; 14 (5): 303—8.

40. Hideyuki K., Yumiko U., Hideo Y. et al. Papular lesions associated with annular elastolytic giant cell granuloma. patients. J Am Acad Dermatol 1989; 21: 398-400.

41. Doulaveri G., Tsagroni E., Giannadaki M. et al. Annular elastolytic giant cell granuloma in a 70-year-old woman. Int J Dermatol 2003; 42 (4): 290-291.

42. Vehring K.H., Bonsmann G., Brocker E.B. et al. Das anulare elastolytische Riesenzellgranulomeine - eine Differentialdiagnose kutaner Granulomatosen. Hautarzt 1991; 42: 391—5.

43. Boussault P., Tucker M.L., Weschler J. et al. Primary cutaneous CD4+ small/medium-sized pleomorphic T-cell lymphoma associated with an annular elastolytic giant cell granuloma. Br J Dermatol 2009; 160 (5): 1126—8.
44. Asahina A., Shirai A., Horita A. et al. Annular elastolytic giant cell granuloma associated with prostate carcinoma: demonstration of human metalloelastase-12 expression. Clin Exp Dermatol 2012; 37: 7072.

45. Lo Schiavo A., Romano F., Alfano R. Unilateral Annular Elastolytic Giant Cell Granuloma in a Hemiplegic Stroke Patient. Am J Dermatopathol 2014; Electronic links: http://journals. Iww. com/ amjdermatopathology/ Citation/ publishahead/Unilateral_Annular_Elastolytic_Giant_Cell. 99212. aspx (date of treatment 17.04.2014)

46. Aso Y., Izaki S., Teraki Y. Annular elastolytic giant cell granuloma associated with diabetes mellitus: a case report and review of the Japanese literature. Clin Exp Dermatol 2011; 36: 917-9.

47. De Oliveira F.L., De Barros Silveira L.K.C., De Miranda Machado A. et al. Hybrid Clinical and Histopathological Pattern in Annular Lesions: An Overlap between Annular Elastolytic Giant Cell Granuloma and Granuloma Annulare? Case Reports in Dermatological Medicine 2012; Electronic links: http://www. ncbi. nlm. nih. gov/pmc/journals/1951 (date of treatment 17.04.2014).

48. Limas C. The spectrum of primary cutaneous elastolytic granulomas and their distinction from granuloma annulare: a clinicopathological analysis. Histopathology 2004; 44 (3): 277—82.
49. Zkaya-bayazit E.O., Kbabani N.Y., Baykal C. et al. Annular elastolytic giant cell granuloma: sparing of a burn scar and successful treatment with chloroquine. Br J Dermatol 1999; 140: 525-30.

50. Vehring K.H., Bonsmann G., Brocker E.B. et al. Das anulare elastolytische Riesenzellgranulomeine - eine Differentialdiagnose kutaner Granulomatosen. Hautarzt 1991; 42: 391—5.

51. Ackerman A.B., Chongchitnant N., Sanchez J. et al. Histologic Diagnosis of Inflammatory Skin Diseases: An Algorithmic Method Based on Pattern Analysis. Williams \& Wilkins, Baltimore, Md, USA, 2nd edition, 1997.

52. Da Veiga Gonsalves R.R., Da Oliveira Viana F., Da Fonseca D.M. Annular elastolytic giant cell granuloma - Case report. An Bras Dermatol 2011; 86 (4): 69_71.

53. Djilali-Bouzina F., Grange F., Krzisch S. et al. Annular elastolytic giant cell granuloma. Ann Dermatol Venereol 2010; 137 (8-9): 536 — 40.

54. Dowling G.B., Wilson-Jones E. Atypical (annular) necrobiosis lipoidica of the face and scalp. Dermatologica 1967; 135: 11-26.

55. Kumari R., Thappa D.M., Chougule A. et al. Granuloma multiforme: a report from India. Indian J Dermatol Venereol Leprol 2009; 75 (3): 296-9.

56. Pock L., Blazkova J., Caloudova H. et al. Annular elastolytic giant cell granuloma causes an irreversible disappearance of the elastic fibres. J Eur Acad Dermatol Venereol 2004; 18: 365-68.

об авторах:

А.В. Патрушев - к.м.н., ассистент кафедры кожных и венерических болезней ФГБВОУ ВПО «Военно-медицинская академия им. С.М. Кирова» МО РФ, Санкт-Петербург

В.Р. Хайрутдинов - д.м.н., ассистент касредры кожных и венерических болезней ФГБВОУ ВПО «Военно-медицинская академия им. С.М. Кирова» МО РФ, Санкт-Петербург

И.Э. Белоусова - д.м.н., доцент, доцент кафредры кожных и венерических болезней ФГБВОУ ВПО «Военно-медицинская академия им. С.М. Кирова» МО РФ, Санкт-Петербург

А.В. Самцов - д.м.Н., просессор, зав. кафедрой кожных и венерических болезней ФГБВОУ ВПО «Военно-медицинская академия им. С.М. Кирова» МО РФ, Санкт-Петербург

\section{Конфликт интересов}

Авторы заявляют об отсутствии потенциального конфликта интересов, требующего раскрытия в данной статье 